\title{
Studies on vaccine development for ovine caseous lymphadenitis
}

\author{
Müjgan İZGÜR ${ }^{1}$, Mehmet AKAN ${ }^{1}$, Ziya İLHAN $^{2}$, Nahit YAZICIOĞLU $^{3}$ \\ ${ }^{1}$ Ankara University, Veterinary Faculty, Department of Microbiology, 06100 Dışkapı, Ankara; ${ }^{2}$ Yüzüncü Y1l University, Veterinary \\ Faculty, Department of Microbiology, Van; ${ }^{3}$ Central Veterinary Control and Research Institute, Etlik, Ankara.
}

Summary: Caseous lymphadenitis (CLA), which is a serious infectious disease of sheep and goats world-wide, has caused significant economic losses in Turkey in recent years. In this study, it was aimed to identify major antigens of Corynebacterium pseudotuberculosis strains isolated in Turkey and to evaluate the efficiency of the vaccine prepared from local strains of $C$. pseudotuberculosis against bacterial challenge in lambs. C. pseudotuberculosis strains were isolated from six different flocks in Turkey and were classified according to their similarities by sodium dodecyl sulphate-polyacrylamide gel electrophoresis (SDSPAGE). SDS-PAGE revealed more than 21 bands ranging in size from $15 \mathrm{kDa}$ to $194 \mathrm{kDa}$ present in different concentrations in $C$. pseudotuberculosis isolates as determined by visual assessment of their approximate molecular masses. Lambs were vaccinated with a bacterin + toxoid + Freund's complete adjuvant (FCA) vaccine, and the vaccine efficiency against bacteriological challenge was evaluated. When a local C. pseudotuberculosis ( $\mathrm{Pl} 18$ ) strain was used and formulated as per $\mathrm{ml}$ of the vaccine, $1.5 \times 10^{8} \mathrm{cfu}$ of $C$. pseudotuberculosis bacterin + toxoid $+1 / 2$ FCA of the toxoid, we obtained encouraging results regarding the potential of this vaccine to control of CLA in sheep.

Key words: Caseous lymphadenitis, Corynebacterium pseudotuberculosis, sheep, vaccine.

\section{Koyun kazeöz lenfadenitisine karşı aşı geliştirme çalışmaları}

Özet: Koyun ve keçilerin önemli bir infeksiyonu olan kazeöz lenfadenitis (KLA), son zamanlarda Türkiye'de önemli ekonomik kayıplara neden olmaktadır. Bu çalışmada, Türkiye'den izole edilen farklı Corynebacterium pseudotuberculosis suşlarının major antijenlerinin belirlenmesi ve lokal suşlardan hazırlanan aşıların, toklularda eprüvasyona karşı koruyuculuğunun ortaya konulması amaçlandı. Altı farklı sürüden izole edilen C. pseudotuberculosis suşları, sodyum dodesil sulfat-poliakrilamid jel elektroforezis (SDS-PAGE) ile analiz edildiğinde, molekül ağırlıkları 15-194 kDa arasında değişen 21 bant tespit edildi. Aş1 denemeleri toklularda gerçekleştirildi ve hayvanlar, C. pseudotuberculosis'in bakterin + toksoid + Freund'un komple adjuvantı (FKA)'nı içeren aşı ile aşılandı. Sonuç olarak, lokal C. pseudotuberculosis (P1 18) suşunun, $1.5 \times 10^{8} \mathrm{cfu} / \mathrm{ml}$ bakterin + toxoid $+1 / 2$ FKA'tı şeklinde formüle edilip, aşı olarak kullanılmasının, koyunları KLA'e karşı korumada başarılı olduğu tespit edildi.

Anahtar sözcükler: Aşı, Corynebacterium pseudotuberculosis, kazeöz lenfadenitis, koyun.

\section{Introduction}

Caseous lymphadenitis (CLA) caused by Corynebacterium pseudotuberculosis is a chronic disease of sheep and goats. Two forms of the disease have been described, an external form (abscesses in superficial lymph nodes and subcutaneous tissues) and an internal form (abscesses located internally in organs and lymph nodes, especially the lungs, liver, kidneys, and mediastinal, bronchial and lumbar lymph nodes). Each form of the disease can cause major economic losses because infected sheep have to be culled from breeding flocks due to poor physical condition or decreased fertility, and carcasses or parts of carcasses are condemned at abattoirs (6).

Although several bacterial species have been isolated from CLA lesions in sheep, C. pseudotuberculosis has been implicated as the major pathogen in this condition (11, 19). C. pseudotuberculosis is a Gram-positive facultative intracellular bacterial rod that produces a phospholipase D (PLD) exotoxin. Both PLD and bacterial cell wall have been determined as possible virulence factors of $C$. pseudotuberculosis $(5,22)$.

Once established, CLA is difficult to eradicate. Chemotherapy is futile, because C. pseudotuberculosis are protected by a thick capsule that surrounds the abscesses $(5,6)$. Prevention of CLA has been limited to good herd management programmes that reduce opportunities for infection of wounds and cull infected animals from the herd. However, these methods have had limited effectiveness. Because of the difficulty in controlling the disease, there has been much investigation into the mechanisms of protective immunity that would

\footnotetext{
${ }^{*}$ This study was supported by TAGEM (Project number: TAGEM/HS/98/08/02).
} 
help in the development of a successful vaccine $(5,6$, 18). To immunise against CLA, different vaccines have been developed. These vaccines contain whole cells (WC) $(3,4)$, cell walls $(\mathrm{CW})(4)$ or toxoid $(6,9)$ of $C$. pseudotuberculosis, or there are combined clostridialcorynebacterial vaccines (9). Several adjuvants (such as, Freund's incomplete adjuvant (6), muramyl dipeptide (3), aluminium salt-based adjuvant (13) have also been used to enhance immunogenicity with variable success. Although large decreases in prevalence of CLA could be achieved by about $70 \%$ of sheep producers by either using a different vaccine or making adjustments to their vaccination programs (17), insufficient data are available to evaluate the protection of the vaccines prepared from local strains of $C$. pseudotuberculosis against bacterial challenge. The purpose of this pilot study was to identify major antigens of $C$. pseudotuberculosis isolated from different sheep flocks in Turkey and to evaluate the efficacy of the vaccine formulated as bacterin + toxoid + Freund's complete adjuvant (FCA) against bacterial challenge in lambs.

\section{Material and Method}

Sample collection and isolation: In order to isolate vaccine strains of $C$. pseudotuberculosis, 65 sheep were selected from 6 different flocks (Ceylanpınar, Gözlü, Polatlı, Tahirova and Altınova Agricultural Administrations Directory and a public farm near Ankara) comprising in total about 20.000 sheep. Clinical inspection of the animals revealed that these 65 sheep had abscessed external lymph nodes (mandibular, superficial cervical, subiliac, lateral retropharyngeal and parotid). The clinical inspection was confirmed at the necropsy of 27 affected animals, when typical abscesses were found. A total of 65 swabs were taken carefully under sterile conditions from abscessed external lymph nodes of the sheep and placed in Stuart's transport medium (Difco Laboratories, Detroit, MI, USA). In addition, abscessed mediastinal and bronchial lymph nodes were taken from the 27 necropsied sheep and placed in physiological saline solution (PSS) (pH. 7.2) with 50\% glycerine for transport to the laboratory. Swabs and lymph node samples were inoculated onto brain-heart infusion agar (BHIA) (Oxoid, CM375, Basingstoke, UK) supplemented with 7\% sheep blood. These BHIA plates were incubated in $5-7 \% \mathrm{CO}_{2}$ atmosphere aerobically for 7 days at $37^{\circ} \mathrm{C}$. Isolates were identified as $C$. pseudotuberculosis by use of previously described methods $(5,11,15)$.

Sodium dodecyl sulphate-polyacrylamide gel electrophoresis (SDS-PAGE): Of the $36 \mathrm{C}$. pseudotuberculosis strains that were isolated in this study, 14 strains were preferred for SDS-PAGE analysis due to their high haemolytic titre (HT) of exotoxins (7) with sheep red blood cells (RBC). To identify potential vaccine strains of C. pseudotuberculosis, these 14 strains were analysed by SDS-PAGE.

Briefly, C. pseudotuberculosis strains were grown in $80 \mathrm{ml}$ brain heart infusion broth (BHIB) (Oxoid, CM225) containing $0.05 \%$ Tween 80 incubated at $37{ }^{\circ} \mathrm{C}$ with a magnetic shaker for $48 \mathrm{~h}$. Cultures were stored at $4^{\circ} \mathrm{C}$ for $12 \mathrm{~h}$ and then centrifuged at $5.000 \mathrm{rpm}$ for 20 min. Supernatant was discarded and pellets were washed 3 times with sterile distilled water. Washed cell pellets were suspended in phosphate buffer solution (PBS) ( $\mathrm{pH}$. 7.2) and pulse-sonicated (Sonic 300, Artek Systems, Farmingdale, NY, USA) 3 times for $10 \mathrm{~min}$ on ice. Whole cell lysates were exposed to diethylether (Merck, 926.5000, KgaA 64271, Darmstadt, Germany) for $6 \mathrm{~h}$ and centrifuged at $6.000 \mathrm{rpm}$ for $30 \mathrm{~min}$. Supernatants were collected and stored $-20{ }^{\circ} \mathrm{C}$ until used (16).

SDS-PAGE was carried out by the method of Laemmli (14) using a $15 \%$ separating gel and a $4 \%$ stacking gel. Protein bands were stained with Coomassie blue. Samples were applied to a Vertical Slab Gel Unit (Hoefer Scientific Instruments, San Francisco, CA, USA). Cluster analysis of the similarity values was performed by the UPGMA algorithm, using the Cluster IC programme (25).

Detection of vaccine strains: C. pseudotuberculosis Pl 18 and C. pseudotuberculosis Cy 5 strains were identified as vaccine strains according to the results of SDS-PAGE and high HT of exotoxins.

Preparation of vaccines: C. pseudotuberculosis $\mathrm{Pl}$ 18 and Cy 5 strains were grown in BHIA supplemented with 7\% fetal bovine serum (Sigma, B2771, St. Louis, MO, USA) incubated in microaerobic atmosphere at 37 ${ }^{\circ} \mathrm{C}$ for $48 \mathrm{~h}$. A single colony was removed from the BHIA, placed in $250 \mathrm{ml}$ of BHIB including $0.1 \%$ Tween 80 and incubated at $37{ }^{\circ} \mathrm{C}$ with shaking for $72 \mathrm{~h}$. The cultures were allowed to settle at $4{ }^{\circ} \mathrm{C}$ for $12 \mathrm{~h}$ and were then centrifuged at $4^{\circ} \mathrm{C}$ for $20 \mathrm{~min}$ at $6.000 \mathrm{rpm}$. Supernatants were removed and were filtered through $0.45 \mu \mathrm{m}$ and $0.22 \mu \mathrm{m}$ filters (Sartorius), respectively. Merthiolate (Lilly, USA) was added to supernatants to a final concentration of $1 / 10.000$ and they were incubated at $4{ }^{\circ} \mathrm{C}$ for $12 \mathrm{~h}$. The HT value of the exotoxins was determined as 1/32 for C. pseudotuberculosis Pl 18 strain and $1 / 16$ for C. pseudotuberculosis Cy 5 strain. Formaldehyde (Sigma, F1635) was added to toxins to a final concentration of $0.6 \%$ and they were incubated at $4^{\circ} \mathrm{C}$ for 7 days. The toxins were then checked for sterility in BHIA and used as toxoid in the vaccine. Pellets were washed three times with PBS ( $\mathrm{pH}$. 7.2) and centrifuged at $4.500 \mathrm{rpm}$ for $30 \mathrm{~min}\left(4^{\circ} \mathrm{C}\right)$. Thereafter, the pellets were prepared in PBS and 10-fold dilutions were made. From these dilutions, $0.1 \mathrm{ml}$ suspension was inoculated onto duplicate plates of BHIA and incubated at $37^{\circ} \mathrm{C}$ for $48 \mathrm{~h}$ 
and colonies were enumerated. The number of microorganisms was estimated spectrophotometrically at $530 \mathrm{~nm}$ and the concentration of bacterins was adjusted by PBS to $1.5 \times 10^{8} \mathrm{cfu} / \mathrm{ml}$ of C. pseudotuberculosis P1 18 and $\mathrm{Cy} 5$ strains. Formaldehyde was added to bacterins to a final concentration of $0.6 \%$ and they were incubated at $4{ }^{\circ} \mathrm{C}$ for 7 days. The bacterins were then checked for sterility and used in the vaccine (13). FCA was purchased from Sigma (F 5881) Chemical Co. Lambs were vaccinated with bacterin + toxoid + FCA in a vaccine that was formulated as per $\mathrm{ml}$ of the vaccine $1.5 \times 10^{8} \mathrm{cfu}$ of C. pseudotuberculosis Pl 18 or Cy 5 strain bacterin + Pl 18 or Cy 5 toxoid + 1/2 FCA of the toxoid.

Lambs: A hundred and forty mixed Akkaraman lambs were used in vaccination trials in this study in the Polatlı Agricultural Administration Directory. The lambs and their mothers had not been previously vaccinated against CLA. Animals approximately six months old were randomly selected and housed in isolation barns, numbered and fed ad libitum. Blood samples were collected and tested by haemolysis inhibition test.

Haemolysis inhibition test (HIT): HIT was carried out as described previously (7). Controls included sheep RBC (no exotoxin) and diluted exotoxin (no serum). The titers $1 / 8$ and higher ones were evaluated as positive in the test.

Vaccination and challenge of lambs: In total, 112 lambs were found to be negative for antibodies against the exotoxin of C. pseudotuberculosis as determined by the HIT. Of these 112 lambs, 90 lambs were allotted at random to 3 groups (30 lambs in each group). Group 1 was vaccinated with a vaccine prepared from $C$. pseudotuberculosis Pl 18 strain; Group 2 with a vaccine prepared from C. pseudotuberculosis Cy 5 strain; and Group 3 was used as a control and was subcutaneously injected with $2 \mathrm{ml}$ PBS. Each lamb in Groups 1 and 2 received two $0.5 \mathrm{ml}$ doses of the vaccine. The vaccine was administered by sc injection in the left axillar region and interval between doses was 4 weeks. For the determination of the vaccine efficacy, four weeks after the second vaccination, the lambs in all groups were challenged intradermally in the right prescapulary lymph node region with $2 \mathrm{ml}$ of a $24 \mathrm{~h}$ broth culture of live $C$. pseudotuberculosis Pl 18 strain $\left(6 \times 10^{6} \mathrm{cfu} / \mathrm{ml}\right)(21)$.

Clinical observation of lambs and bacterial examinations: Lambs were monitored clinically throughout the 7 weeks after the challenge. In week 7, 8 lambs from each group were randomly selected, necropsied and abscessed lymph nodes were counted (1) and cultured for bacterial examinations.

Statistical analysis: Statistical analysis was performed using SPSS (V.11.0) package program. Comparisons of the results were examined by the chi-square test (30).

\section{Results}

Isolation: In total 36 (39.1\%) C. pseudotuberculosis strains were isolated, of which $27(29.3 \%)$ originated from external lymph nodes and 9 (9.7\%) from lungs or associated lymph nodes. Smears of colonies revealed Gram-positive coryneform microorganisms. The isolates were identified as C. pseudotuberculosis on the basis of motility, catalase, urease, nitrate, methyl red and fermentation of glucose, xylose, mannitol, lactose, sucrose, trehalose, salicin, inositol, maltose, galactose and arabinose.

SDS-PAGE: SDS-PAGE revealed more than 21 bands ranging in size from $15 \mathrm{kDa}$ to $194 \mathrm{kDa}$ present in different concentrations in isolates as determined by visual assessment of their approximate molecular masses. The 15, 25.7, 31.2, 36, 43, 66.5, 80 and $194 \mathrm{kDa}$ bands were consistently recognised and $25.7,43$ and $80 \mathrm{kDa}$ were determined as major bands in $14 \mathrm{C}$. pseudotuberculosis strains. Bands of each strain were compared with protein profiles of other strains and their similarity rate was determined. When the similarity coefficiencies of 14 strains were evaluated, two subgroups were seen to have formed. The first group included C. pseudotuberculosis $\mathrm{Pl} 18$ strain and contained 8 strains that were identical (similarity coefficient 71-100), while the second group included $C$. pseudotuberculosis Cy 5 strain and contained 6 strains that were identical (similarity coefficient 71-100).

Clinical, necropsy and bacteriological findings in lambs: External lymph nodes were enlarged in 5, 9 and 24 lambs after challenge with C. pseudotuberculosis Pl 18 strain in Groups 1-3, respectively. The internal form of CLA was observed in 2, 2 and 8 of the 8 lambs necropsied in Groups 1-3 respectively. C. pseudotuberculosis was isolated from 2/8 necropsied lambs in Group 1, 3/8 lambs in Group 2 and 7/8 lambs in Group 3 (Table 1). Using the ki-square test, the proportion of vaccinated lambs (Groups 1 and 2) that developed CLA lesions and the isolation ratio of $C$. pseudotuberculosis were significantly less $(\mathrm{p}<0.001)$ than in the control lambs.

Table 1. Comparison of the effects of the vaccine prepared from C. pseudotuberculosis Pl 18 (Group 1) and Cy 5 (Group 2) strains with control group (Group 3). There were 30 lambs in each group, of which 8 were necropsied in week 7 after the challenge.

Tablo 1 C. pseudotuberculosis P1 18 (Grup 1) ve Cy 5 (Grup 2) suçlarından hazırlanan aşıların etkinliğinin control grubu (Grup 3) ile karşılaştırılması. Eprüvasyondan 7 hafta sonar her grupta bulunan 30 kuzudan 8'ine nekropsi uyguland.

\begin{tabular}{lccc}
\hline Findings & $\begin{array}{c}\text { Pl 18 } \\
\text { (Group 1) }\end{array}$ & $\begin{array}{c}\text { Cy 5 } \\
\text { (Group 2) }\end{array}$ & $\begin{array}{c}\text { Control group } \\
\text { (Group 3) }\end{array}$ \\
\hline External form & $5 / 30$ & $9 / 30$ & $24 / 30$ \\
Internal form & $2 / 8$ & $2 / 8$ & $8 / 8$ \\
Isolation & $2 / 8$ & $3 / 8$ & $7 / 8$ \\
\hline
\end{tabular}




\section{Discussion and Conclusion}

CLA has been reported in many countries worldwide (5). In sheep, it has serious economic consequences, especially in the USA and Australia (20). The disease has long been known in Turkey (12), but recently the prevalence of CLA has accelerated in Turkish sheep breeding, especially in large sheep flocks (11). Although several bacterial organisms have been isolated from CLA lesions, C. pseudotuberculosis has been implicated as the major pathogen in this condition (19). In the present study, a total of 36 (39.1\%) $C$. pseudotuberculosis strains were isolated from sheep materials. Other microorganisms isolated from cultures of the materials included Micrococcus spp., Staphylococcus aureus, Streptococcus epidermidis and Pseudomonas aeruginosa.

To develop an effective vaccine for CLA it is necessary to target major determinant antigens of $C$. pseudotuberculosis. The exotoxin PLD and bacterial cell wall lipids have been identified as virulence factors of the organism. Brown and colleagues (6) reported that the presence of anti-exotoxin antibodies in the initial bacterial multiplication period may limit local spread and general dissemination of $C$. pseudotuberculosis. Some variation in the ability of the different strains of $C$. pseudotuberculosis to produce exotoxins, their ability to kill white mice and their haemolytic activity were detected. A highly significant relationship between the number of mice dying and the haemolytic activity has been demonstrated (23). The SDS-PAGE technique has been successfully employed to characterise protein antigens of $C$. pseudotuberculosis $(2,10,16)$. Muckle and co-workers (16) showed that antibodies to at least seven antigens of a WC lysate of C. pseudotuberculosis were present in the serum of naturally infected sheep and goats. Three antigens of about 31.5, 68 and $120 \mathrm{kDa}$ in size were consistently recognised by all infected animal sera. In this study, analyses of proteins of $C$. pseudotuberculosis strains revealed more than 21 bands in gel and the 80, 43 and $25.7 \mathrm{kDa}$ bands were detected as major protein antigens. The C. pseudotuberculosis $\mathrm{Pl}$ 18 and Cy 5 strains were preferred as vaccine strains due to their high HT and due to them being representative of their groups in SDS-PAGE analyses.

Colostrum-deprived lambs vaccinated by im with $10 \mathrm{mg}$ (dry weight) of C. pseudotuberculosis WC or CW and immunity-challenged by iv injection of $3.1 \times 10^{4} \mathrm{cfu}$ of C. pseudotuberculosis were significantly protected from CLA, as demonstrated by fewer abscesses and organisms in the lungs of lambs vaccinated with WC or $\mathrm{CW}$ than in control lambs (4). In ten male 9-week-old goats vaccinated via sc with formalized exotoxin containing Freund's incomplete adjuvant, at necropsy, 5 of the 10 vaccinated goats did not have lesions of CLA, 3 had abscesses limited to the inoculation site and 2 had disseminated bacterial lesions. Of the 5 non-vaccinated controls, 4 had disseminated abscesses and 1 had a single abscess in an internal node (6). Piontkowski and Shivvers, (18) reported that vaccination with commercial vaccine (Caseous D-T, Colorado Serum Co. Denver, USA) including C. pseudotuberculosis bacterin + toxoid protected sheep against challenge by exposure to live $C$. pseudotuberculosis $\left(1.95 \times 10^{5} \mathrm{cfu} / \mathrm{ml}\right)$ in sc injection. In this study, the isolation ratio of $C$. pseudotuberculosis and symptoms of CLA after challenge in Groups 1 and 2 were lower than in the control group (Table 1).

Although the lambs and their mothers had not been previously vaccinated against CLA, out of the 140 lambs, 28 lambs were found to be positive by HIT in this research. This could be attributed to 28 lamb sera giving false positive results due to cross-reaction with other bacteria (8).

Effective vaccination against CLA may require stimulation of the host reticuloendothelial system with an accompanying adjuvant $(3,23)$. In the present study, FCA was preferred for vaccination in lambs because insufficient date are available to evaluate its adjuvant activity in sheep. Significant injection site reactions were not observed in experimental lambs compared with control lambs throughout the study. The potency of FCA allows lower doses of bacterin + toxoid vaccine, thus reducing the incidence of site reactions.

Several vaccine trials have been performed using different combination of vaccines in sheep $(4,13,18)$ but, absolute protective immunity was not established. This could attribute that the $C$. pesudotuberculosis is a facultative intracellular parasite, thus development both humoral immunity and cell-mediated immunity.

CLA is characterised by abscessed external and internal lymph nodes $(1,6)$. In this study, there were significantly fewer abscesses and fewer organisms, especially in Group 1 than in the control group $(\mathrm{p}<0.001)$. Although absolute immunity was not established in Groups 1 and 2 , the vaccine contained a local $C$. pseudotuberculosis ( $\mathrm{Pl} 18$ ) strain and formulated as per $\mathrm{ml}$ of the vaccine $1.5 \times 10^{8} \mathrm{cfu}$ of $C$. pseudotuberculosis bacterin + toxoid $+1 / 2$ FCA of the toxoid, we obtained encouraging results regarding the potential of this vaccine to control of CLA in sheep.

\section{Acknowledgements}

The authors thank Dr. Hidayet Keçeli for field studies. This work was supported by Republic of Turkey, Ministry of Agriculture and Rural Affairs, General Directorate of Agricultural Research (Project number: TAGEM/HS/98/08/02). 


\section{References}

1. Batey RG (1986): Frequency and consequence of caseous lymphadenitis in sheep and lambs slaughtered and a western Australian abattoir. Am J Vet Res, 47, 482-485.

2. Braithwaite CE, Smith EE, Songer JG, Reine AH (1993): Characterization of detergent-soluble proteins of Corynebacterium pseudotuberculosis. Vet Microbiol, $\mathbf{3 8}$, 59-70.

3. Brogden KA, Chedid L, Cutlip RC, Lehmkuhl HD, Sacks J (1990): Effect of muramyl dipeptide on immnunogenicity of Corynebacterium pseudotuberculosis whole-cell vaccines in mice and lambs. Am J Vet Res, 51, 200-202.

4. Brogden KA, Cutlip RC, Lehmkuhl HD (1984): Comparison of protection induced in lambs by Corynebacterium pseudotuberculosis whole cell and cell wall vaccines. Am J Vet Res, 45, 2393-2395.

5. Brown CC, Olander HJ (1987): Caseous lymphadenitis of goats and sheep: A review. Vet Bull, 57, 1-11.

6. Brown CC, Olander HJ, Biberstein EL, Morse SM (1986): Use of a toxoid vaccine to protect goats against intradermal challenge exposure to Corynebacterium pseudotuberculosis. Am J Vet Res, 47, 1116-1119.

7. Burrell DH (1980): A haemolysis inhibition test for detection of antibody to Corynebacterium ovis exotoxin. Res Vet Sci, 28, 190-194.

8. Cummins CS (1962): Chemical composition and antigenic structure of cell walls of Corynebacterium, Mycobacterium, Actinomyces and Athrobacter. J Gen Microbiol, 28, 3505-3510.

9. Eggleton DG, Doidge CV, Middleton HD, Minty DW (1991): Immunisation against ovine caseous lymphadenitis: Efficacy of monocomponent Corynebacterium pseudotuberculosis toxoid vaccine and combined clostridialcorynebacterial vaccines. Aust Vet J, 68, 320-321.

10. Ellis JA, Hawk DA, Mills KW, Pratt DL (1991): Antigen specificity and activity of ovine antibodies induced by immunization with Corynebacterium pseudotuberculosis culture filtrate. Vet Immunol Immunopathol, 28, 303-316.

11. Izgür M, Akan M, Ilhan Z (1999): Koyunlarda kazeöz lenfadenitis olgularından izole edilen etkenler. Ankara Univ Vet Fak Derg, 46, 43-50.

12. Keskintepe H (1976): Stabilization of Corynebacterium ovis antigens for serum agglutination test. Furat Üniv Vet Fak Derg, 3, 84-93.

13. LeaMaster BR, Shen DT, Gorham JR, Leathers VW, Wells HD (1987): Efficacy of Corynebacterium pseudotuberculosis bacterin for the immunological protection of sheep against development of caseous lymphadenitis. Am J Vet Res, 48, 869-872.

14. Laemmli UK (1970): Cleavage of structural proteins during the assembly of the head of bacteriophage T4. Nature, 227, 680-685.
15. Muckle CA, Gyles CL (1982): Characterization of strains of Corynebacterium pseudotuberculosis. Can J Comp Med, 46, 206-208.

16. Muckle CA, Menzies PI, Hwang TY, van Wesenbeeck M (1992): Analysis of the immunodominant antigens of Corynebacterium pseudotuberculosis. Vet Microbiol, 30, 47-58.

17. Paton MW, Walker SB, Rose SB, Watt GF (2003): Prevalence of caseous lymphadenitis and usage of caseous lymphadenitis vaccines in sheep flocks. Aust Vet J 81, 9195.

18. Piontkowski MD, Shivvers DW (1998): Evaluation of a commercially available vaccine against Corynebacterium pseudotuberculosis for use in sheep. J Am Vet Med Assoc, 212, 1765-1768.

19. Renshaw HW, Graff VP, Gates NL (1979): Visceral caseous lymphadenitis in thin ewe syndrome: Isolation of Corynebacterium, Staphylococcus, and Moraxella spp. from internal abscesses in emaciated eyes. Am J Vet Res, 40, 1110-1114.

20. Schreuder BEC, ter Laak EA, Dercksen DP (1994): Eradication of caseous lymphadenitis in sheep with the help of a newly developed ELISA technique. Vet Rec, 135, 174-176.

21. Simon MC, Alonso JL, Muzquiz JL, Girones O, Ortega C, Garcia J (1992) : Vaccination contre la maladie des abces du mouton etude de reficacite des quatre vaccines testes sur souris. Vet Med, 168, 35-41.

22. Songer JG, Libby SJ, Iandolo JJ, Cuevas WA (1988): Biochemical and genetic characterization of Corynebacterium pseudotuberculosis. Am J Vet Res, 49, 223-226.

23. Sutherland SS, Speijers EJ, Andres B (1989): Comparison of the exotoxins of four strains of Corynebacterium pseudotuberculosis. Res Vet Sci, 47, 190-194.

24. Thrusfield M (1986): Veterinary Epidemiology. Butterworth Co., London, pp. 175-186.

25. Vauterin L, Awings J, Kerters K (1993): Protein electrophoresis and classification. 251-272. In: Goodfellow M, O'Donnell AG (Eds), Handbook of New Bacterial Systematics. Academic Press, London.

Geliş tarihi: 12.03.2007 / Kabul tarihi: 07.11.2009

Yazışma adresi

Prof. Dr. Mehmet Akan

Ankara Üniversitesi Veteriner Fakültesi

Mikrobiyoloji Anabilim Dalı

06110 Dışkapı / Ankara

akan@veterinary.ankara.edu.tr 